\title{
Behavior of trace metals in Mytilus edulis during a reciprocal transplant field experiment
}

\author{
G. Roesijadi, J. S. Young, A. S. Drum and J. M. Gurtisen \\ Battelle, Pacific Northwest Laboratories, Marine Research Laboratory, 439 West Sequim Bay Road, Sequim, \\ Washington 98382, USA
}

\begin{abstract}
Marine mussels Mytilus edulis were transplanted reciprocally from relatively pristine Sequim Bay to a metal-contaminated site at Tacoma (both Washington State, USA) and vice versa. We studied temporal patterns of trace metal accumulation by the mussels, metal incorporation into subcellular compartments (low molecular weight, metal-binding proteins, lysosome-like vesicles) and condition index (a measure of animal health) in a field experiment. Analysis of seawater from the Tacoma site showed elevated concentrations in all the metals examined in this study; i.e. copper, zinc, cadmium, mercury, and silver. Values fluctuated with time; peak concentrations were 105 ppb copper, $113 \mathrm{ppb}$ zinc, $5.4 \mathrm{ppb}$ cadmium, $0.0189 \mathrm{ppb}$ mercury, and $0.13 \mathrm{ppb}$ silver. These values were $255 \times$ $188 \times, 103 \times, 47 \times$ and $138 \times$ the respective metal concentrations in Sequim Bay. With the exception of cadmium, the tissues of indigenous mussels at the Tacoma site reflected the high seawater metal concentrations. Mussels transferred from Sequim to Tacoma accumulated metals rapidly and approached or exceeded the metal concentrations in Tacoma mussels. General patterns were complicated by fluctuations in metal concentrations. Loss of metals following reciprocal transfer was relatively rapid in copper and silver values which were close to background levels after 4 wk and slower with zinc and mercury (24 wk or longer to background). Patterns of accumulation and loss and organs for concentration were specific for individual metals. Gills and digestive gland, for example, varied in their abilities to concentrate different metals and were often more sensitive indicators of metal bioconcentration than the whole organism. Gills were also examined for copper, cadmium and zinc on low-molecular-weight metal-binding proteins, high-molecular-weight proteins $\left(<70,000 \mathrm{M}_{\mathrm{f}}\right)$, and pelleted fraction. A highly significant correlation $(\mathrm{r}=0.87, \mathrm{p}<0.01)$ existed between copper in whole tissues and copper associated with the 3 fractions identified above. Changes in copper in the subcellular compartments paralleled changes in the whole tissues in this study. X-ray microanalysis provided evidence for the localization of zinc as being primarily in the kidneys and was useful for examining the metal composition of organs which could not be easily excised and analyzed using other procedures. Measurement of condition index indicated that Tacoma mussels were stressed by field conditions; condition index was reduced in both transplanted and indigenous groups of mussels at Tacoma. The time at which the reduction was sustained over time coincided with the time at which the trace metals in Tacoma seawater had risen to extremely high concentrations.
\end{abstract}

\section{INTRODUCTION}

Numerous studies have shown that concentrations of trace metals are elevated in marine animals whose habitats reflect conditions of metal-enrichment from anthropogenic sources (reviewed by Phillips, 1980). However, with few exceptions (e.g. Davies and Pirie, 1978; Eganhouse and Young, 1978; Breteler et al., 1981; Widdows et al., 1981) biological processes associated with metal exposure (e.g. accumulation, release, physiological responses) have seldom been studied in field experiments. Such studies would be of value in furthering our understanding of the responses of organisms which occur in areas of elevated metal concentrations.

The present paper investigates the responses of Mytilus edulis to trace metals (copper, zinc, cadmium, mercury, silver) in a reciprocal-transplant field experiment. Study sites were located in Sequim Bay (a relatively pristine embayment) and a metal-contaminated location adjacent to Tacoma, Washington (USA). The transplant from Sequim Bay to Tacoma was designed to elicit changes associated with metals exposure as a function of time, while the reverse experiment was designed to simulate recovery from exposure. Biological responses examined over a 6 mo period included 
(1) accumulation or loss of copper, zinc, cadmium, mercury, and silver in gill, digestive gland, and whole mussel; (2) association of copper, zinc, and cadmium with low-molecular-weight metal-binding proteins of gills; (3) ultrastructural localization of metals; and (4) bivalve condition index. Taken together, examination of these responses was expected to provide information on the changes of metal concentrations as a function of time, the compartmentalization of the metals into gills and digestive glands, the role of subcellular compartments believed to function in metals detoxification (reviewed by Coombs and George, 1978; Roesijadi, 1981; George, 1982), and stress (Bayne et al., 1980).

\section{EXPERIMENTAL DESIGN}

Mussels were transplanted from Sequim Bay, Washington, to Tacoma, Washington, and from Tacoma to Sequim Bay. Mussels not transplanted served as reference groups. All groups including the reference were placed in subtidally located experimental cages and sampled over a 6 mo interval $(0 \mathrm{~d}, 2 \mathrm{wk}, 4 \mathrm{wk}, 8 \mathrm{wk}$, $16 \mathrm{wk}, 24 \mathrm{wk}$ ) from January to June, 1982.

The basic experimental design is shown in Fig. 1. Assuming stable conditions over time in both external environments and reference mussels, responses of transplanted mussels would be expected to approach those of the respective reference group after a period of time which would be determined as a result of this study. As will be seen later, however, uncontrollable aspects of the external environment precluded strict adherence to this hypothetical model.

\section{METHODS}

Spherical cages were constructed from polyethylene shrimp traps and placed at the respective study sites: adjacent to Battelle Marine Research Laboratory in Sequim Bay and adjacent to Point Defiance Ferry Dock and Tacoma Yacht Club. Each cage was suspended in ca. $8 \mathrm{~m}$ of water, about $3 \mathrm{~m}$ above the bottom, by means of a submerged buoy.

Mussels ( 3.5 to $4.5 \mathrm{~cm}$ total shell length) were collected from intertidal sites located near the areas where cages were installed. Mussels were scrubbed clean of epifauna then placed in polyethylene mesh bags $(\sim 3 \times 2 \mathrm{~cm}$ mesh) before placement in cages, each bag containing the required number $(55 / \mathrm{bag})$ for a single sampling. At each sampling date a single bag was removed from each cage by SCUBA divers. Following collection, the bags were drained of seawater and placed on ice for transport to the laboratory where

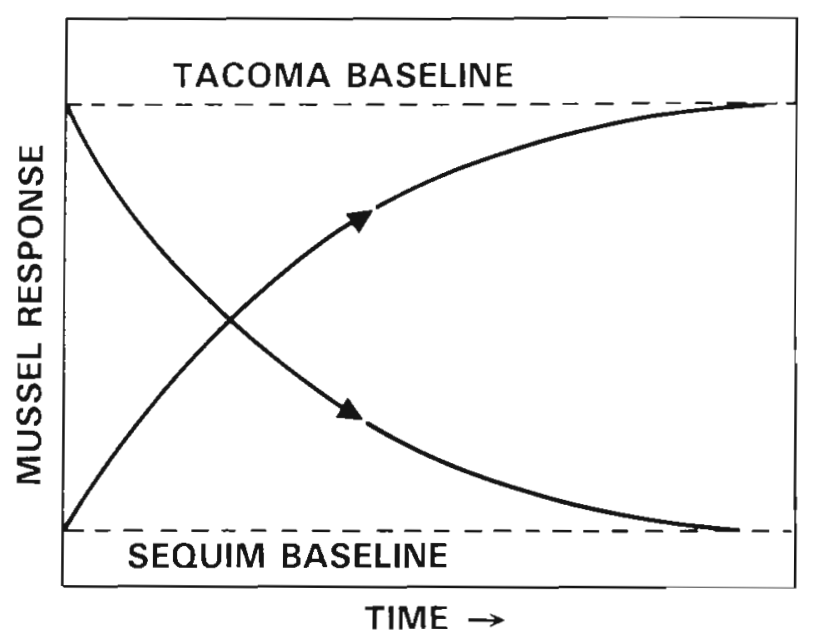

Fig. 1. Hypothetical model for reciprocal transplant experiment

they were held in a $4{ }^{\circ} \mathrm{C}$ incubator overnight prior to processing. Allocation of mussels for different procedures occurred as follows: 10 mussels: dissect for $\mathrm{Cu}$, $\mathrm{Cd}, \mathrm{Zn}$, and $\mathrm{Ag}$ measurements; 10 mussels: dissect for mercury measurements; 10 mussels: dissect and pool organs for metal-binding proteins; 10 mussels: condition index; 3 mussels: fix for $x$-ray microanalysis. Dead mussels, usually as empty shells, were counted after each sampling. Mortalities were not correlated with differences in experimental treatments. Maximum mortality was observed at the $24 \mathrm{wk}$ sampling with 7 to 14 dead mussels bag $^{-1}$. Otherwise, mortalities were minimal $\left(2.7 \pm 2.5\right.$ [S.D.] bag $\left.^{-1}\right)$.

Analysis of trace metals in tissues. Gills, digestive glands, and remaining tissue were dissected from individual mussels. Wet and dry $\left(60^{\circ} \mathrm{C}\right.$ for $\left.5 \mathrm{~d}\right)$ weights were determined for samples destined for $\mathrm{Cu}, \mathrm{Cd}, \mathrm{Zn}$, and $\mathrm{Ag}$ analyses. Dried tissues were digested and analyzed by atomic absorption spectrophotometry as described in Roesijadi (1980). Metal concentrations were expressed as $\mu \mathrm{g} \mathrm{g}^{-1} \mathrm{dry}$ weight. Procedures for mercury analysis followed those of Roesijadi (1982). Values were expressed as $\mu \mathrm{g} \mathrm{Hg} \mathrm{g}^{-1}$ dry weight after conversion to dry weight using wet weight: dry weight ratios determined from above. Analysis of National Bureau of Standards (NBS) certified oyster tissue was used to validate our analytical procedures. Our measurements for the oysters were within the limits of analytical variability provided by NBS for $\mathrm{Cu}$, $\mathrm{Cd}, \mathrm{Zn}, \mathrm{Hg}$, and Ag. Whole-mussel metal concentrations were calculated as a composite of the individual tissue components.

Analysis of metal-binding proteins. Gill tissues from mussels in each treatment group were dissected, pooled, and frozen immediately at $-65^{\circ} \mathrm{C}$ for storage. Subsequently, partially thawed samples were prepared as described in Roesijadi and Hall (1981). 
Briefly, the sample was homogenized and centrifuged at $80,000 \mathrm{~g}$ for $1.5 \mathrm{~h}$. The supernatant was applied to a Sephadex G-75 column, and fractions were collected for $\mathrm{Cu}, \mathrm{Cd}, \mathrm{Zn}$, or $\mathrm{Hg}$ analyses. Absorbance at $280 \mathrm{~nm}$ was monitored with a flow-through UV-monitor. All preparatory and chromatographic procedures were conducted at $4{ }^{\circ} \mathrm{C}$ or on ice and in a nitrogen atmosphere. All buffers were saturated with nitrogen gas. Samples to be used for $\mathrm{Cu}, \mathrm{Cd}$, and $\mathrm{Zn}$ analysis were homogenized in the presence of $1 \% 2$-mercaptoethanol (Ryden and Deutsch, 1978). Mercaptoethanol was omitted for samples to be used for $\mathrm{Hg}$ analyses (Roesijadi and Drum, 1982).

$X$-ray microanalysis. Samples of gill, digestive gland and kidney were excised from live mussels from each collection and fixed for $x$-ray microanalysis in a phosphate-buffered glutaraldehyde fixative. The fixative contained $\mathrm{Na}_{2} \mathrm{~S}$ to minimize the loss of certain metals during subsequent processing of the tissues (George and Pirie, 1980) and enough $\mathrm{NaCl}$ to make the fixative either isosmotic or slightly hyperosmotic to Sequim Bay and Tacoma seawater (salinities shown in Table 1). Only Day 0 control mussels and those from $24 \mathrm{wk}$ of exposure were processed further. These samples were then embedded in resin, sectioned at $1500 \AA$, mounted on berylium grids, and carbon coated. X-ray microanalysis was performed on a JEOL $100 \mathrm{CX}^{\circledR}$ TEM/STEM electron microscope equipped with a $\mathrm{LaB}_{6}$ electron source. KEVEX ${ }^{\circledR} 30 \mathrm{~mm}^{2} \mathrm{SiLi}$ detector, and Tracor Northern multichannel analyzer.

Condition index. Condition index of mussels was determined as described by Lawrence and Scott (1982) using the relation:

Condition index $=$ (dry weight soft tissue/shell cavity volume) $\times 100$.

Analysis of seawater. Seawater at the respective study sites was analyzed for temperature, salinity, $\mathrm{pH}$, and the trace metals $\mathrm{Cu}, \mathrm{Cd}, \mathrm{Zn}, \mathrm{Hg}$, and Ag. Temperature, salinity and $\mathrm{pH}$ were determined using conventional procedures. $\mathrm{Cu}, \mathrm{Cd}$, and $\mathrm{Ag}$ in seawater were determined as described by Boyle and Edmond (1974) with the following modifications (Bloom and Crecelius, in press): $\mathrm{pH}$ adjustment was to $1.90 \pm 0.05$ (this optimized Ag and Cd precipitation without reducing yields for the other metals); samples were filtered after precipitation through acid-cleaned $0.4 \mu$ Nucleopore filters; filters were digested in concentrated nitric acid $(0.25 \mathrm{ml}$ acid in a $5 \mathrm{ml}$ volumetric flask). The digests were analyzed on a Perkin-Elmer 5000 atomic absorption (aa) spectrophotometer equipped with a graphite furnace and Zeeman background correction. Zn was determined by direct injection into the furnace cuvette. Hg was measured using a modification of the method of Bothner and Robertson (1975) as described by Roesijadi (1982).

\section{RESULTS}

\section{Temperature, salinity, pH and trace metal concentrations in seawater}

Values for seawater temperature, salinity, and $\mathrm{pH}$ (Table 1) showed some differences in the 2 study sites with respect to these parameters. Salinity was generally lower at Tacoma $(26 \pm 3.8$ S.D. \%o) when compared to Sequim Bay $(30 \pm 1.9 \%)$ indicating greater freshwater impact at Tacoma. Temperatures were higher at Tacoma although the magnitude of the difference did not exceed $1 \mathrm{C}^{\circ}$ at any of the sampling dates. Little difference was noted in $\mathrm{pH}$ between the two sites. Temporal patterns were observed with all 3 parameters. Increase in temperature was associated with general warming resulting from transition from winter to summer. $\mathrm{pH}$ fluctuations may have resulted from enhanced primary productivity in spring and early summer.

Measurements for $\mathrm{Cu}, \mathrm{Zn}, \mathrm{Cd}, \mathrm{Hg}$, and Ag clearly showed that the seawater at the Tacoma site was impacted by elevated concentrations (Table 2 inserts in Fig. 2 to 6 ). Temporal patterns which existed with all

Table 1. Temperature, salinity and $\mathrm{pH}$ at transplant sites

\begin{tabular}{|c|c|c|c|c|c|c|c|}
\hline \multirow[t]{2}{*}{ Station } & \multirow[t]{2}{*}{ Parameters } & \multicolumn{6}{|c|}{ Sampling interval } \\
\hline & & $0 \mathrm{~d}$ & $2 w k$ & $4 w \mathrm{k}$ & $8 \mathrm{wk}$ & $16 \mathrm{wk}$ & $24 w k$ \\
\hline \multirow[t]{3}{*}{ Sequim } & Temperature & $6.5^{\circ} \mathrm{C}$ & 7.3 & 6.5 & 7.5 & 9.6 & 12.4 \\
\hline & Salinity & $32 \%$ & 31 & 31 & $27^{\circ}$ & 30 & - \\
\hline & $\mathrm{pH}$ & 7.76 & 7.70 & 7.9 & 7.79 & 8.05 & 8.10 \\
\hline \multirow[t]{3}{*}{ Tacoma } & Temperature & $7.0^{\circ} \mathrm{C}$ & 8.0 & 7.2 & 8.1 & 9.8 & 13.5 \\
\hline & Salinity & $23 \%$ & 28 & 20 & 28 & 29 & 29 \\
\hline & $\mathrm{pH}$ & 7.68 & 7.66 & - & 7.67 & 7.97 & 8.00 \\
\hline
\end{tabular}


5 metals at this site generally paralleled each other. These patterns were characterized by initially high values, followed by a decline to levels which were stable through the eighth week. A large increase was observed in all the metals at $16 \mathrm{wk}$. At $24 \mathrm{wk}$, however, decreases were observed in $\mathrm{Cu}_{1} \mathrm{Zn}$, and $\mathrm{Hg}$ and increases in $\mathrm{Cd}$ and $\mathrm{Ag} . \mathrm{Cu}, \mathrm{Zn}$, and $\mathrm{Hg}$ could be assigned to one group whose patterns over time were most similar to each other, while $\mathrm{Cd}$ and Ag could be assigned to another.

Concentrations of metals in Sequim Bay seawater were low and reflective of an uncontaminated environment. $\mathrm{Cu}$ and $\mathrm{Hg}$ exhibited similar patterns over time. Other metals appeared to fluctuate independently. The relatively high Ag value at Day 0 was uncharacteristic of Sequim Bay and may have reflected Ag contamination of that particular sample. Fluctuations in the Sequim Bay seawater were negligible when compared on the scale of the Tacoma seawater.

\section{Trace metals in mussel tissue}

$\mathrm{Cu}$. Mussel tissues sampled at Day 0 , the initiation of the study, exhibited copper concentrations reflective of copper contamination of the Tacoma study site (Table 3). Copper concentrations were 7.7, 5.4, and $5.8 \times$ higher in gills, digestive glands, and whole mus- sels, respectively, from Tacoma when compared to those from Sequim. Examination of the relative partitioning into gill or digestive gland indicated a higher concentration of copper in digestive gland of Sequim mussels, whereas concentrations in gills and digestive glands were similar in mussels from Tacoma.

Transfer of mussels from Sequim to Tacoma resulted in a pattern of copper accumulation which was complicated by the fluctuating seawater copper concentrations. As indicated earlier, a relatively high initial seawater copper concentration declined to lower levels which were stable for at least $8 \mathrm{wk}$, then increased again. Copper accumulation by mussels was rapid and evident in the high concentrations in tissues at the 2 wk sampling (Fig. 2 ST, TT). Following this initial accumulation, which did not appear to be affected by the transient decline in the seawater copper between 2 and $8 \mathrm{wk}$, copper in all biological compartments (i.e. gills, digestive gland, and whole mussel) generally paralleled the changes in the seawater copper concentration. Gill copper concentrations of the Sequim to Tacoma transplant (Fig. 2 ST) exceeded that in the Tacoma reference group (Fig. 2, TT) after Week 8. Levels in the former attained a maximum at $16 \mathrm{wk}$ of over $400 \mu \mathrm{g} \mathrm{Cu} \mathrm{g} \mathrm{g}^{-1}$ dry weight compared to $200 \mu \mathrm{g} \mathrm{g}^{-1}$ in the reference group, possibly reflecting an adaptation toward exclusion of copper or more efficient outward transport of copper from the gills (either to the

Table 2. Trace metal concentrations in Tacoma and Sequim seawater $\left(\mu \mathrm{gl}^{-1}\right)$

\begin{tabular}{|c|c|c|c|c|c|c|c|}
\hline \multirow[t]{2}{*}{ Station } & \multirow[t]{2}{*}{ Metal } & \multicolumn{6}{|c|}{ Sampling interval } \\
\hline & & $0 \mathrm{~d}$ & $2 \mathrm{wk}$ & $4 \mathrm{wk}$ & $8 w k$ & $16 \mathrm{wk}$ & $24 \mathrm{wk}^{\mathrm{k}}$ \\
\hline \multirow[t]{5}{*}{ Sequim } & $\mathrm{Cu}$ & 0.73 & 0.79 & 0.82 & 0.83 & 0.41 & 0.62 \\
\hline & $\mathrm{Zn}$ & 0.8 & 1.0 & 1.4 & 1.0 & 0.6 & 0.5 \\
\hline & $\mathrm{Cd}$ & 0.116 & 0.101 & 0.077 & 0.061 & 0.052 & 0.072 \\
\hline & $\mathrm{Hg}$ & 0.0009 & 0.0010 & 0.0014 & 0.0012 & 0.0004 & 0.0017 \\
\hline & $\mathrm{Ag}$ & 0.017 & $<0.001$ & $<0.001$ & 0.002 & 0.001 & $<0.001$ \\
\hline \multirow[t]{5}{*}{ Tacoma } & $\mathrm{Cu}$ & 28.4 & 3.02 & 3.76 & 3.88 & 104.7 & 92.3 \\
\hline & $\mathrm{Zn}$ & 55 & 11.8 & 9.5 & 10.5 & 113 & 108 \\
\hline & $\mathrm{Cd}$ & 0.971 & 0.166 & 0.113 & 0.238 & 5.4 & 6.7 \\
\hline & $\mathrm{Hg}$ & 0.0104 & 0.0028 & 0.0023 & 0.0031 & 0.0189 & 0.0048 \\
\hline & $\mathrm{Ag}$ & 0.108 & 0.019 & 0.017 & 0.014 & 0.138 & 0.183 \\
\hline
\end{tabular}

Table 3. Day 0. Cu, Cd, $\mathrm{Zn}$, and $\mathrm{Hg}$ in mussel tissues $\left(\mu \mathrm{g} \mathrm{g}^{-1}\right.$ dry weight; $\left.\overline{\mathrm{X}} \pm 1 \mathrm{~S} . \mathrm{E} . \mathrm{n}=10\right)$

\begin{tabular}{|c|c|c|c|c|c|c|}
\hline \multirow[t]{2}{*}{ Station } & \multirow[t]{2}{*}{ Organ } & \multicolumn{5}{|c|}{ Metal } \\
\hline & & $\mathrm{Cu}$ & $\mathrm{Zn}$ & $\mathrm{Cd}$ & $\mathrm{Hg}$ & $\mathrm{Ag}$ \\
\hline \multirow[t]{3}{*}{ Sequim } & Gill & $9.8 \pm 0.5$ & $67 \pm 2$ & $3.3 \pm 0.2$ & $0.133 \pm 0.008$ & $0.067 \pm 0.022$ \\
\hline & Digestive gland & $15.0 \pm 1.0$ & $72 \pm 4$ & $7.0 \pm 0.9$ & $0.160 \pm 0.009$ & $0.176 \pm 0.034$ \\
\hline & Whole animal & $5.8 \pm 0.3$ & $89 \pm 13$ & $5.2 \pm 0.9$ & $0.102 \pm 0.005$ & $0.064 \pm 0.008$ \\
\hline \multirow[t]{3}{*}{ Tacoma } & Gill & $75.0 \pm 12.0$ & $102 \pm 9$ & $3.6 \pm 0.6$ & $0.836 \pm 0.005$ & $0.725 \pm 0.134$ \\
\hline & Digestive gland & $81.0 \pm 9.0$ & $166 \pm 23$ & $7.1 \pm 1.0$ & $0.361 \pm 0.023$ & $0.255 \pm 0.064$ \\
\hline & Whole animal & $34 \pm 3$ & $430 \pm 56$ & $6.6 \pm 1.1$ & $0.478 \pm 0.028$ & $0.168 \pm 0.029$ \\
\hline
\end{tabular}


Fig. 2. Mytilus edulis. Concentrations $\quad(\overline{\mathrm{X}} \pm 1 \quad$ S.E.; $\mathrm{n}=10$ ) of copper in gill, digestive gland, and whole individual in Sequim (SS) and Tacoma (TT) reference mussels and in transplants from Sequim to Tacoma (ST) and Tacoma to Sequim (TS). Insert to TT: seawater copper at Tacoma; insert to SS: seawater copper at Sequim

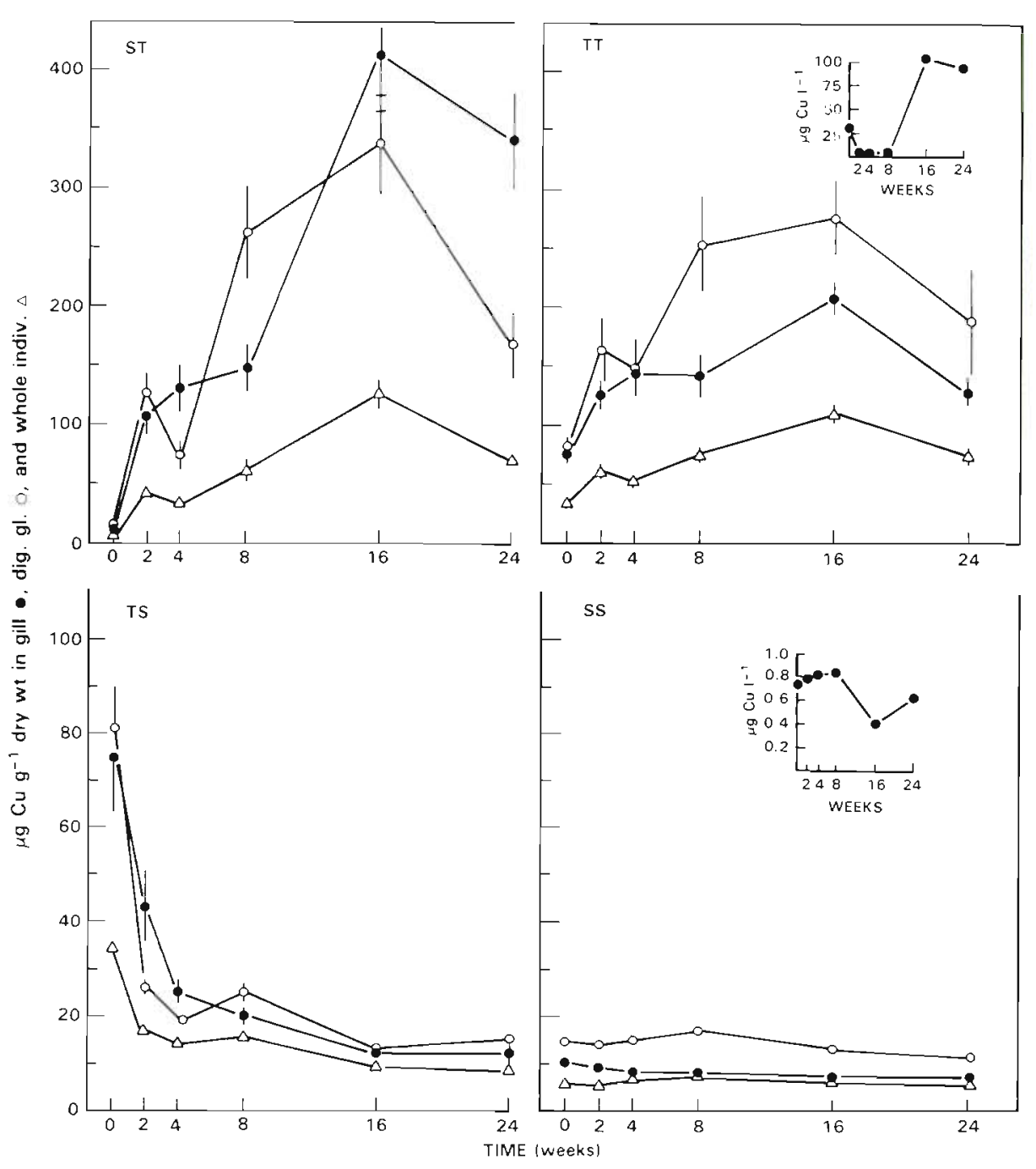

Sequim (Table 3). All 3 compartments (gill, digestive gland, whole mussel) of Tacoma individuals exhibited enhanced zinc concentrations. However, in both Sequim and Tacoma mussels, an organ not specifically analyzed and localized in the 'rest of tissue' was the major contributor to the total zinc in the individual. Thus, values for zinc in the whole individual were higher in concentration than in either gill or digestive and reflected the contribution of this compartment. Its identity as the kidney is discussed later.

Transfer of mussels from Sequim to Tacoma resulted in an increase in the whole body zinc to high concentrations (Fig. 3 ST), presumably as a result of accumulation in kidneys. Changes of zinc in the gill and digestive gland with time were minor. The rate of $\mathbf{Z n}$ accumulation by the whole body was linear over the entire $24 \mathrm{wk}$ duration. The pattern of accumulation in the Tacoma reference group (Fig. 3 TT) was not similar to the transplants. Instead of a linear increase with time, zinc in the whole mussel of this group appeared to reach a steady-state (with considerable variability)
$\mathrm{Zn}$. Zinc in mussels collected from Tacoma at Day 0 also showed elevations when compared to those from
$161 \mathrm{~d}$, respectively, for the slow compartments. The behavior of the fast compartments dominated overall release rates, and total values approached those of the Sequim reference (SS) after $4 \mathrm{wk}$. 


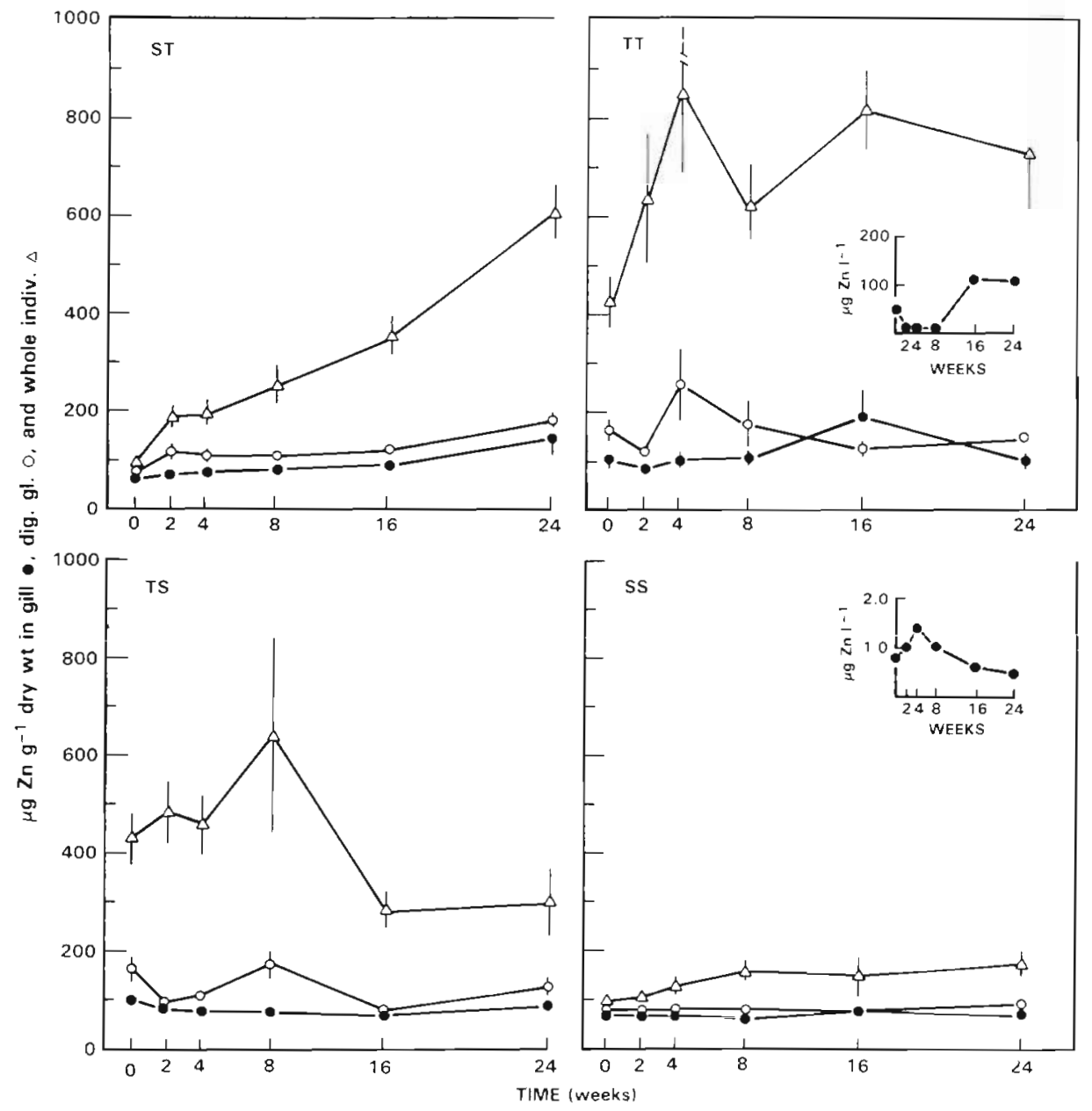

Fig. 3. Mytilus edulis. Zinc concentrations in gill, digestive gland, and whole individual. Other details as in Fig. 2, except for zinc instead of copper

after $2 \mathrm{wk}$. Transfer of mussels from Tacoma to Sequim did not result in an immediate decrease in whole body zinc concentrations (Fig. 3 TS). A lag of at least 8 wk was observed before a decline occurred and suggested the presence of a relatively long-term storage compartment. Changes were minor in the gill or digestive gland. Zinc concentrations stabilized after $16 \mathrm{wk}$ at a level 1.5 times higher than those in Sequim reference mussels (Fig. $3 \mathrm{SS}$ ).

Cd. Cadmium concentrations in mussels from Sequim and Tacoma did not differ from each other at Day 0 (Table 3). An influence of the enhanced seawater cadmium concentration at the Tacoma site was not readily apparent. An increase in cadmium concentrations over time in the digestive gland was evident in mussels associated with the Sequim site by transplant or origin (Fig. 4 ST, TS, SS). Cadmium in gills was diminished when compared to cadmium in digestive glands or whole animal in all 4 groups.

$\mathrm{Hg}$. Concentrations of mercury in Tacoma mussels were considerably higher than those of Sequim mussels at Day 0 (Table 3). Enrichment factors for Tacoma mussels when compared to those from Sequim were
$6.3 \times, 2.3 \times$, and $4.7 \times$, respectively, for gills, digestive gland, and whole individual. While mercury in Sequim mussels appeared to be uniformly concentrated in gill, digestive gland, and whole individuals; gills concentrated mercury in Tacoma mussels. Following transplant of Tacoma mussels to Sequim Bay (Fig. 5 TS), the decline in the gill mercury concentration was linear with time. In digestive gland, however, mercury concentrations increased considerably up to Week 4 before a decline was observed. A decline of mercury in the whole mussel was not observed until mercury in the digestive gland fell below its original value measured at Day 0. A similar phenomenon was apparent in Tacoma mussels (Fig. 5 TT) during the first $8 \mathrm{wk}$ of exposure when seawater mercury had declined from initially high levels. Gill mercury concentrations decreased in response to the decrease in the seawater mercury, while concentrations in digestive glands increased. It appears that the kinetics of mercury distribution during the initial depuration phase as in Fig. 5 TS and the early stages of Fig. 5 TT is associated with a decline in gills and increase in digestive gland due to internal transport and redistribution. These 
Fig. 4. Mytilus edulis. Concentrations of cadmium in gill, digestive gland, and whole individual. Other details as in Fig. 2, except for cadmium, instead of copper
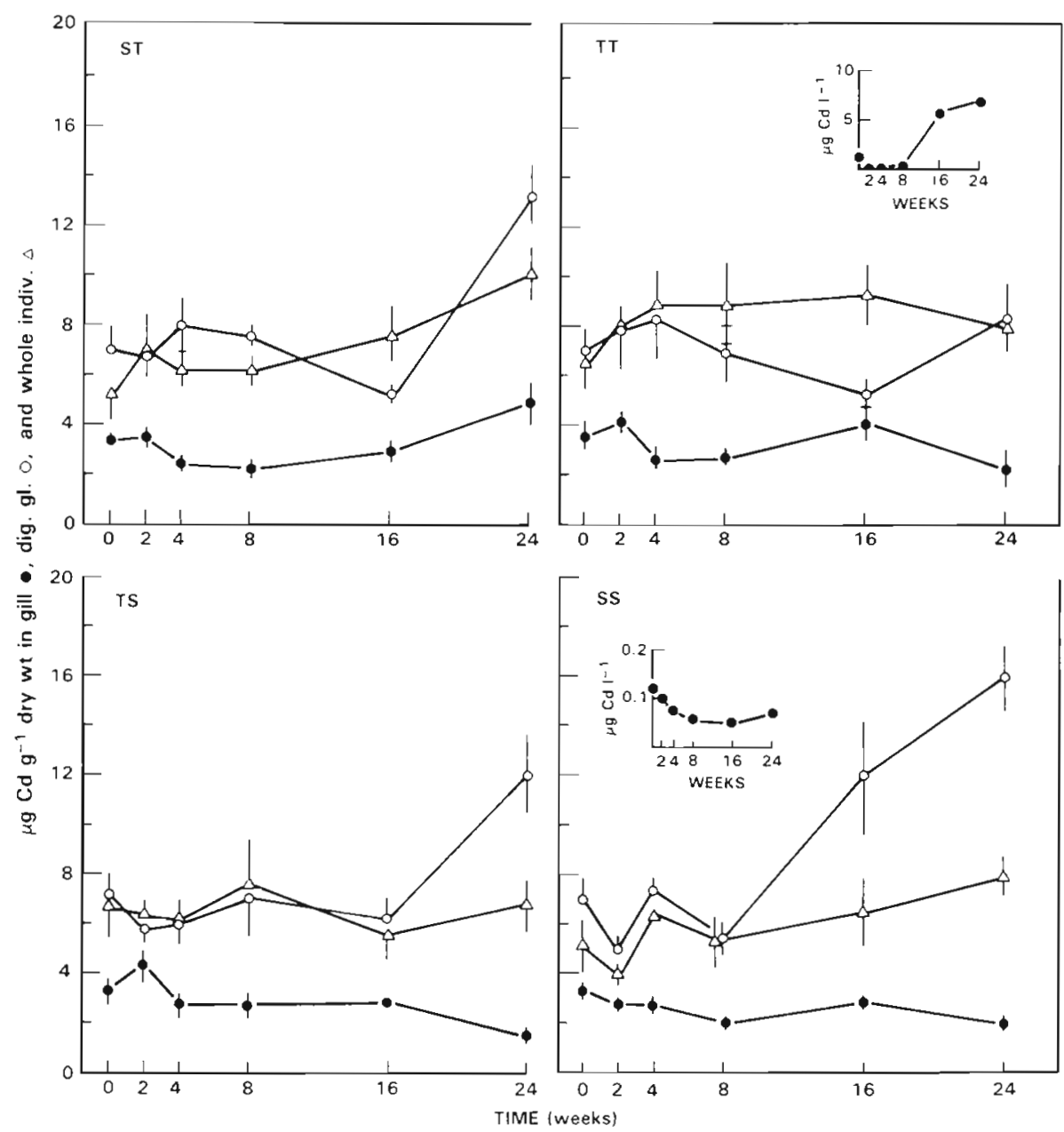

changes are highly suggestive of interorgan transport to the digestive gland and temporary storage in that organ. It is possible that mercury must first be transformed to an excretable form in the digestive gland prior to release. Transfer of mussels from Sequim to Tacoma (Fig. 5 ST) resulted in changes of mercury which were generally similar to the response to copper. Mercury in gills followed the same pattern over time as the gill copper; seawater mercury also paralleled the seawater copper. Mercury profiles for digestive glands and whole individuals were also similar to those for copper if the $24 \mathrm{wk}$ samples are discounted. Unlike mercury in gills, that in digestive gland and whole animal did not undergo a decline as might be expected from the large decrease in the seawater mercury concentrations. This pattern was consistent with that proposed above for mercury redistribution in the mussel.

Ag. As with the other metals, silver concentrations in the Tacoma mussels at Day 0 were elevated when compared to those of Sequim mussels (Table 3). Silver in whole mussels from Tacoma was $2.7 \times$ greater than in those at Sequim. Differences in relative distribution among organs was also evident in the 2 populations. The gills of Tacoma mussels had an enrichment factor of $11 \times$ over those from Sequim. Silver in Sequim mussels was concentrated in the digestive gland rather than gills, while the reverse was true in Tacoma mussels. The gills were most sensitive to changes in seawater silver (Fig. $6 \mathrm{ST}, \mathrm{TT}$, TS). Thus, accumulation of silver in mussels at or transferred to Tacoma (Fig. 6 ST, TT) and loss of silver in mussels transferred from Tacoma to Sequim (Fig. $6 \mathrm{TS}$ ) were observed mainly as changes in the gill $(\mathrm{t} 1 / 2=10.2 \mathrm{~d}$ for TS gills using single compartment exponential model). Silver accumulation by gills of mussels transplanted to Tacoma (Fig. $6 \mathrm{ST}$ ) exceeded that of the Tacoma reference group (Fig. 6 TT). Little change was observed in whole body Ag concentrations due to the small biomass of the gill.

\section{Low-molecular-weight metal-binding proteins}

A representative Sephadex G-75 chromatogram depicting the distribution of copper, cadmium, and 

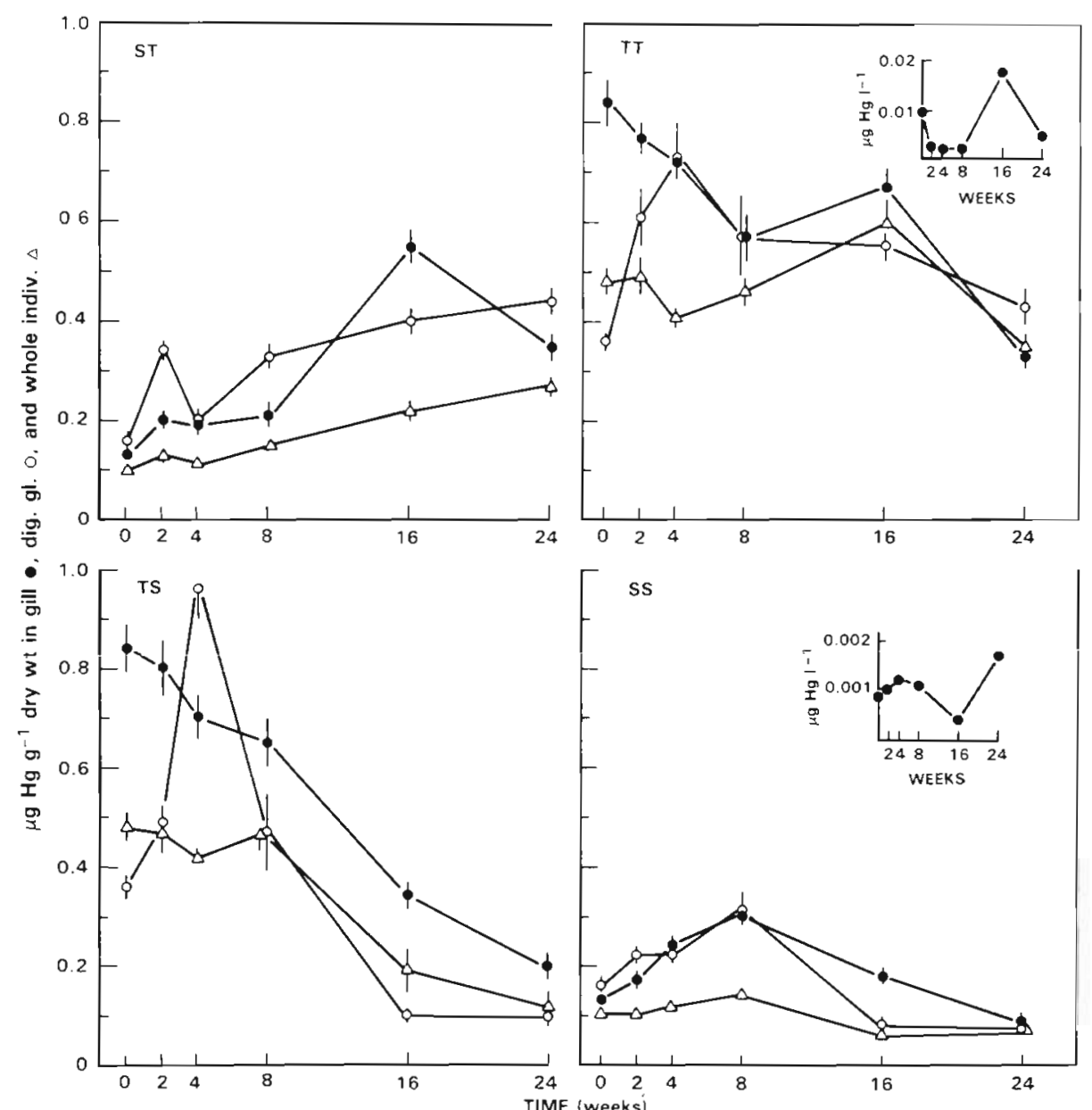

Fig. 5. Mytilus edulis. Concentrations of mercury in gill, digestive gland, and whole individual. Other details as in Fig. 2, except for mercury instead of copper

zinc in the cytosolic fraction of gills is shown in Fig. 7. Metals were associated with high-molecular-weight proteins ( $\mathrm{HMWP}>70,000 \mathrm{M}_{\mathrm{r}}$ Peak I), metal-binding proteins (MBP; Peak II), and substances $<3,000 \mathrm{M}_{\text {ᄃ }}$ (Peak III). Occasionally, Peak II would separate into a doublet peak. These were considered as a single pool for the purpose of estimation of metals on the metalbinding protein fraction. Although separate analyses were also conducted for mercury-binding proteins, these data were excluded due to unacceptably high column mercury recoveries suggestive of mercury contamination of the column packing material. Calculations of column recoveries for copper, cadmium, and zinc resulted in values of $95.6 \% \pm 2.5 \%$ (S.E.), $101.9 \% \pm 4.9 \%$, and $91.6 \% \pm 36 \%$, respectively.

Metals associated with the metal-binding proteins, high-molecular-weight proteins and the pelleted fraction of gill tissue were expressed as $\mu \mathrm{g} \mathrm{g}^{-1}$ wet tissue weight as in Roesijadi (1980) and analyzed further. No clear patterns were observed with either cadmium or zinc bound to the 3 subcellular fractions and other parameters such as time, exposure concentration, or tissue metal concentrations. The lack of any such correlations can, most likely, be attributed to inherent variability associated with the relatively stable concentrations of these metals in whole gills during this study (Fig. 3 and 4). With copper, however, concentrations in the whole gill were highly correlated $(\mathrm{p}<0.01)$ with copper on metal-binding proteins $(r=0.87)$ (Fig. 8), high molecular weight proteins $(\mathrm{r}=0.87$ ) (Fig. 9), and pellet $(\mathrm{r}=0.84)$ (Fig. 10). In effect, changes in copper in these 3 subcellular compartments paralleled changes in the whole gill, with $\mathrm{Cu}$ on metal-binding and high molecular weight proteins exhibiting identical relationships $(r \sim 0.99)$.

\section{$\mathrm{X}$-ray microanalysis}

Gill, digestive gland, and kidney tissues were analysed qualitatively by $x$-ray microanalysis. Heavy elements in gills and digestive glands were undetectable. However, kidneys of all samples examined contained appreciable amounts of zinc in electron-dense, intracellular vesicles, granules, and large concentric concretions (Fig. 11 and 12). Concretions also contained some iron, calcium, phosphorus, chlorine, and traces of barium, aluminum, silicon, lead, copper, and 
Fig. 6. Mytilus edulis. Concentrations of silver in gill, digestive gland, and whole individual. Other details as in Fig. 2, except for silver instead of copper

cadmium. The high zinc content found in the kidney by $x$-ray microanalysis indicated that the large amounts of zinc measured in the 'rest of tissue' (evident in Fig. 3 as high whole mussel zinc values) were contained in the kidney.

\section{Condition index}

Measurements of condition index indicated no significant difference in mussels at the Tacoma and Sequim sites at Day 0 (Table 4). However, subsequent changes during the course of the experiment indicated highly significant effects due to the transplant $(p<0.005)$, sampling time $(p<0.001)$ and the interaction between these 2 factors ( $p<0.001 ; 2$-way analysis of variance). Table 4 shows that the 2 groups at Sequim behaved similarly (comparison between SS and TS) and the 2 at Tacoma behaved similarly (ST and TT), while the 2 at Sequin were different from the 2 at Tacoma (comparison between SS and TS combined against ST and TT combined). While some of the observed fluctuations in condition index can be attributed to seasonal changes and associated nutritional and reproductive states, mussels at the Tacoma site were on a downward trend after the $8 \mathrm{wk}$ sampling, while those at the Sequim site were not. It appears from the condition index data that the Tacoma site was stressful to both indigenous mussels and those transplanted from Sequim. The time interval at which condition index of the Tacoma groups diverges from those at Sequim coincided with our first observations of large increases in seawater trace metals concentrations at the Tacoma site (Table 2 ; inserts Fig. 2 to 6).

\section{DISCUSSION}

The Tacoma site was highly contaminated with metals. Large fluctuations in seawater metal concentrations suggested a transient source whose composition or volume changed with time. An attempt to determine the magnitude of the impacted area following measurement of seawater copper concentrations in the vicinity of the experimental site (unpubl.) indicated that the high concentration of metals was extremely localized. Changes in the seawater metal concentrations could be associated with changes in the metal 


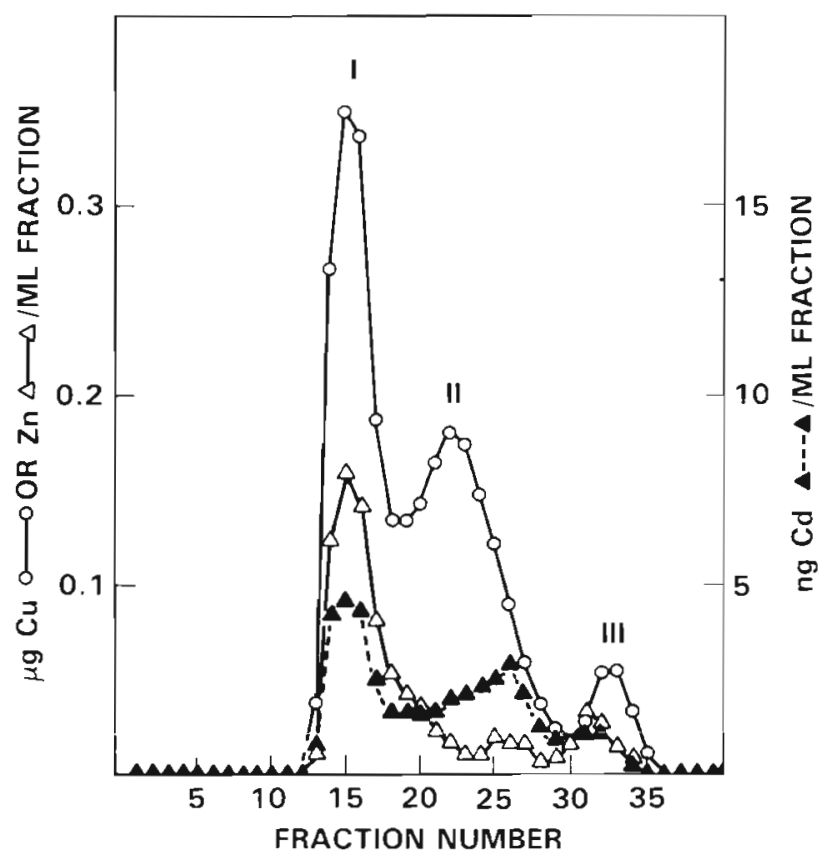

Fig. 7. Mytilus edulis. Representative chromatographic profile of copper, zinc, and cadmium following separation of the soluble fraction on Sephadex G-75. Peak I: high molecular weight proteins; Peak II: metal-binding proteins; Peak III: low molecular weight substances $<3000$ daltons

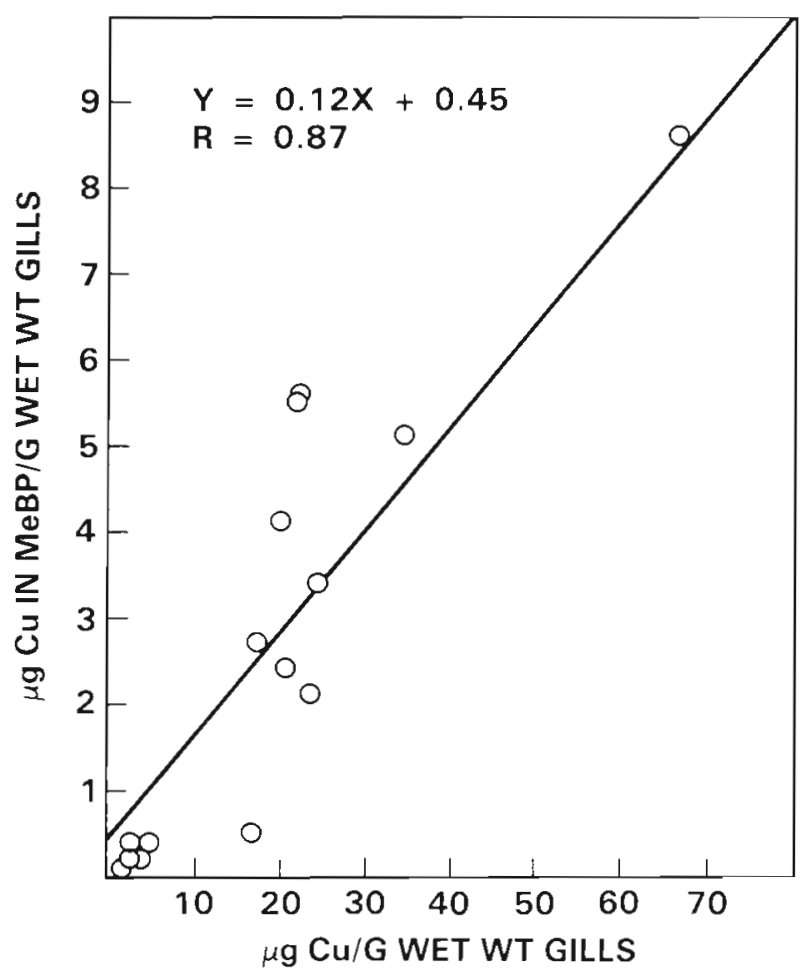

Fig. 8. Mytilus edulis. Relation between copper bound to lowmolecular-weight metal-binding proteins (MeBP) and copper in whole gill

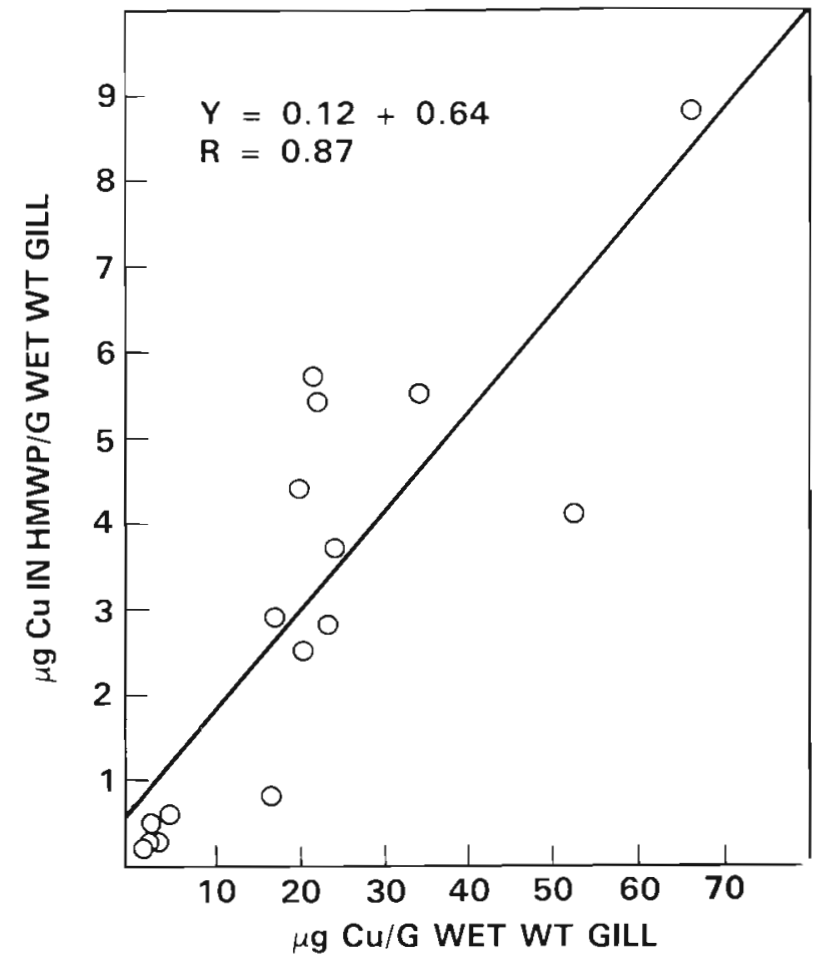

Fig. 9. Mytilus edulis. Relation between copper bound to high molecular weight proteins (HMWP) and copper in the whole gill

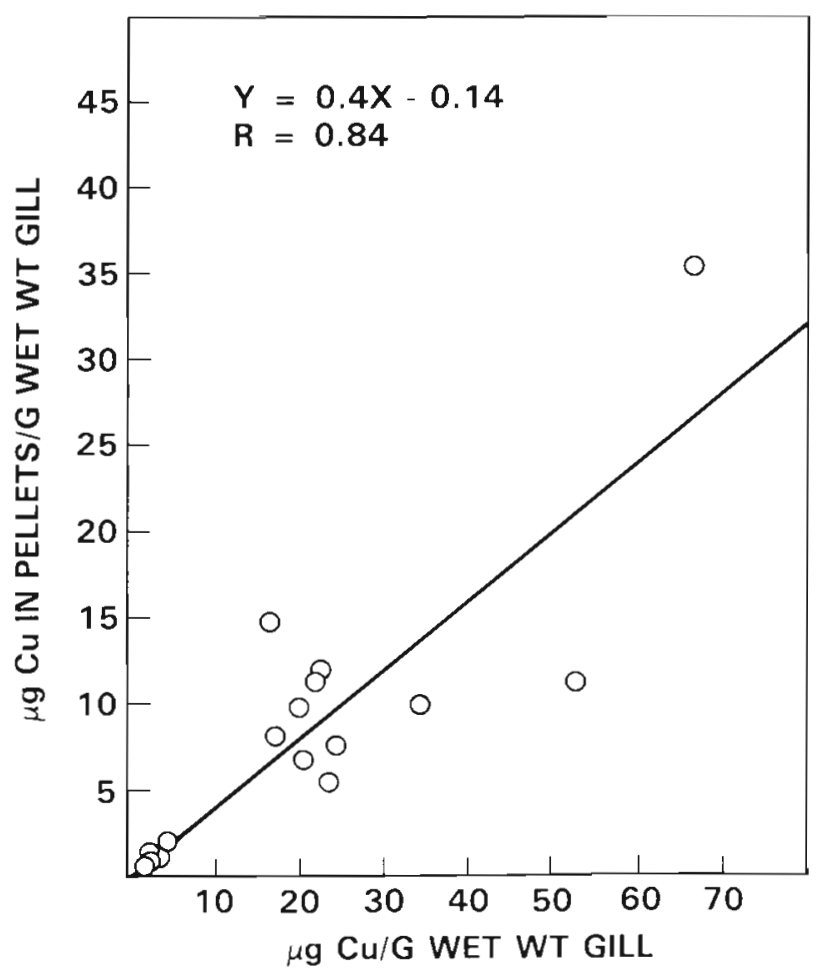

Fig. 10. Mytilus edulis. Relation between copper bound to pellet and copper in the whole gill 

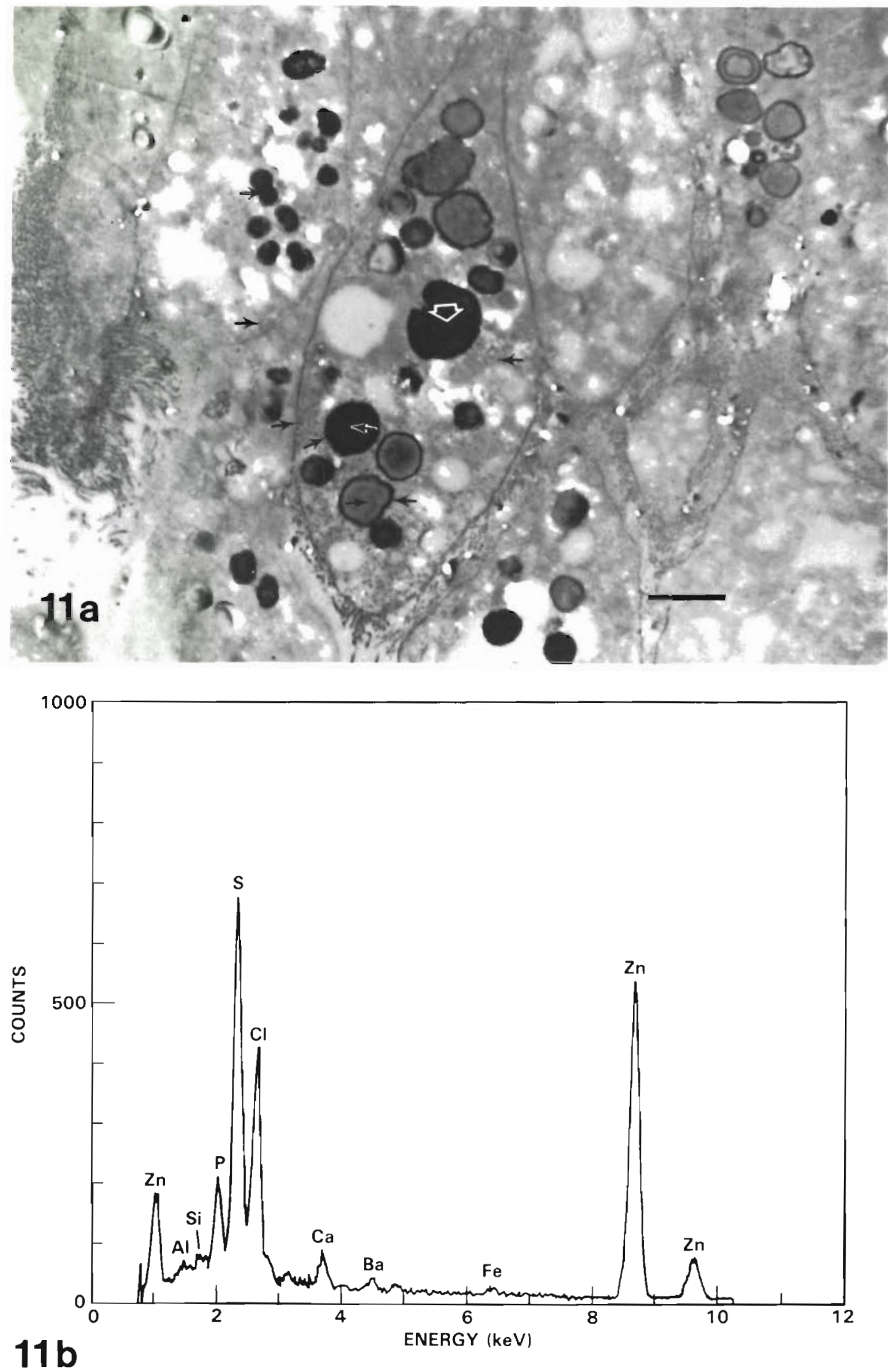

Fig. 11. Mytilus edulis. (a) STEM photomicrograph of kidney section from a mussel transferred from Tacoma to Sequim Bay for 24 wk. Arrows: points or areas $\mathrm{x}$-ray microanalyzed. Broad white arrow: area represented by spectrum in Fig. $11 \mathrm{~b}$. All analyses showed some zinc. Dense bodies are probably incipient concretions contained in lysosomes. Bar $=2 \mu \mathrm{m}$. (b) Spectrum of dense granule indicated by broad white arrow in Fig. $11 \mathrm{a}$. Sulfur peak is caused by $\mathrm{Na}_{2} \mathrm{~S}$ added to the fixative 

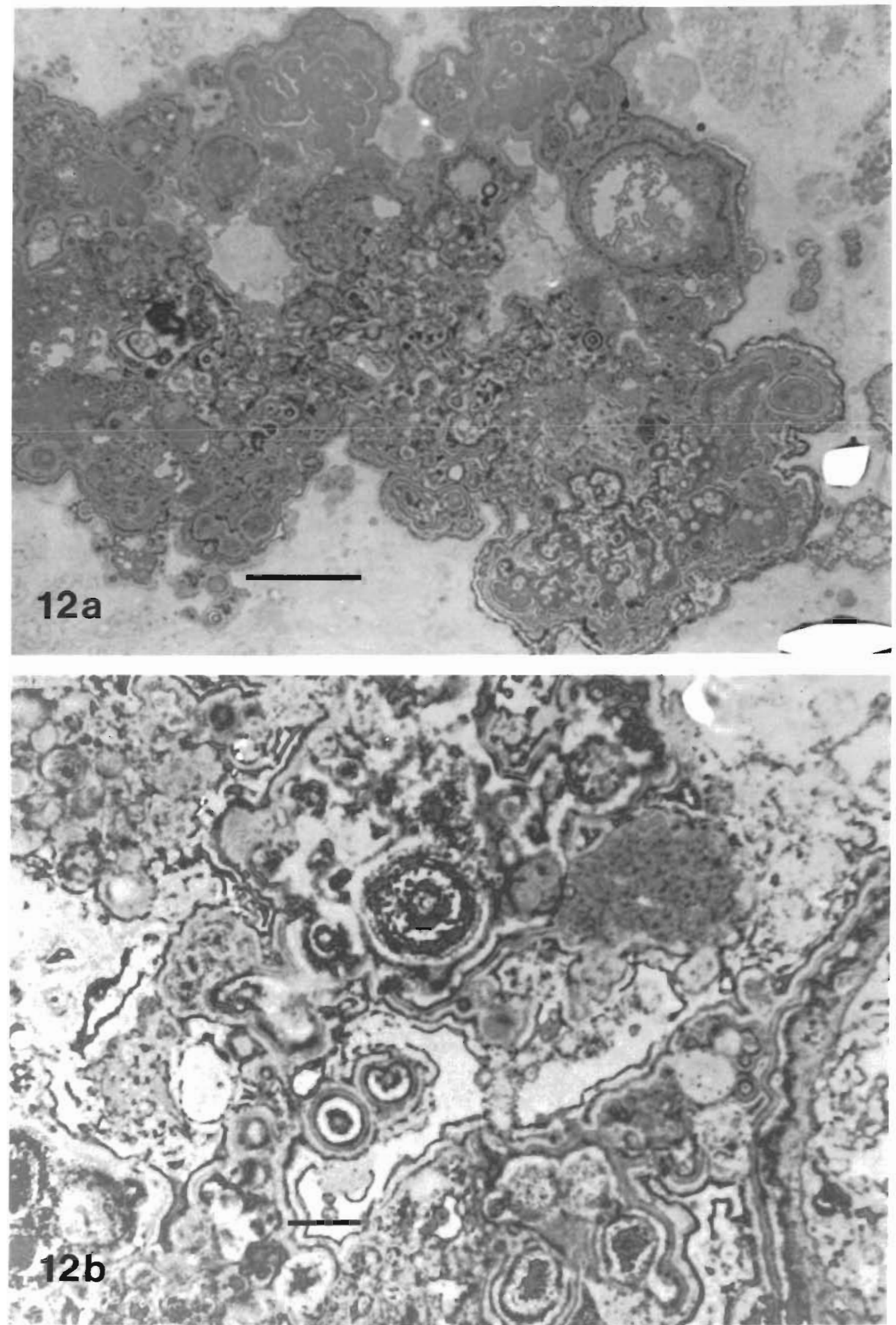


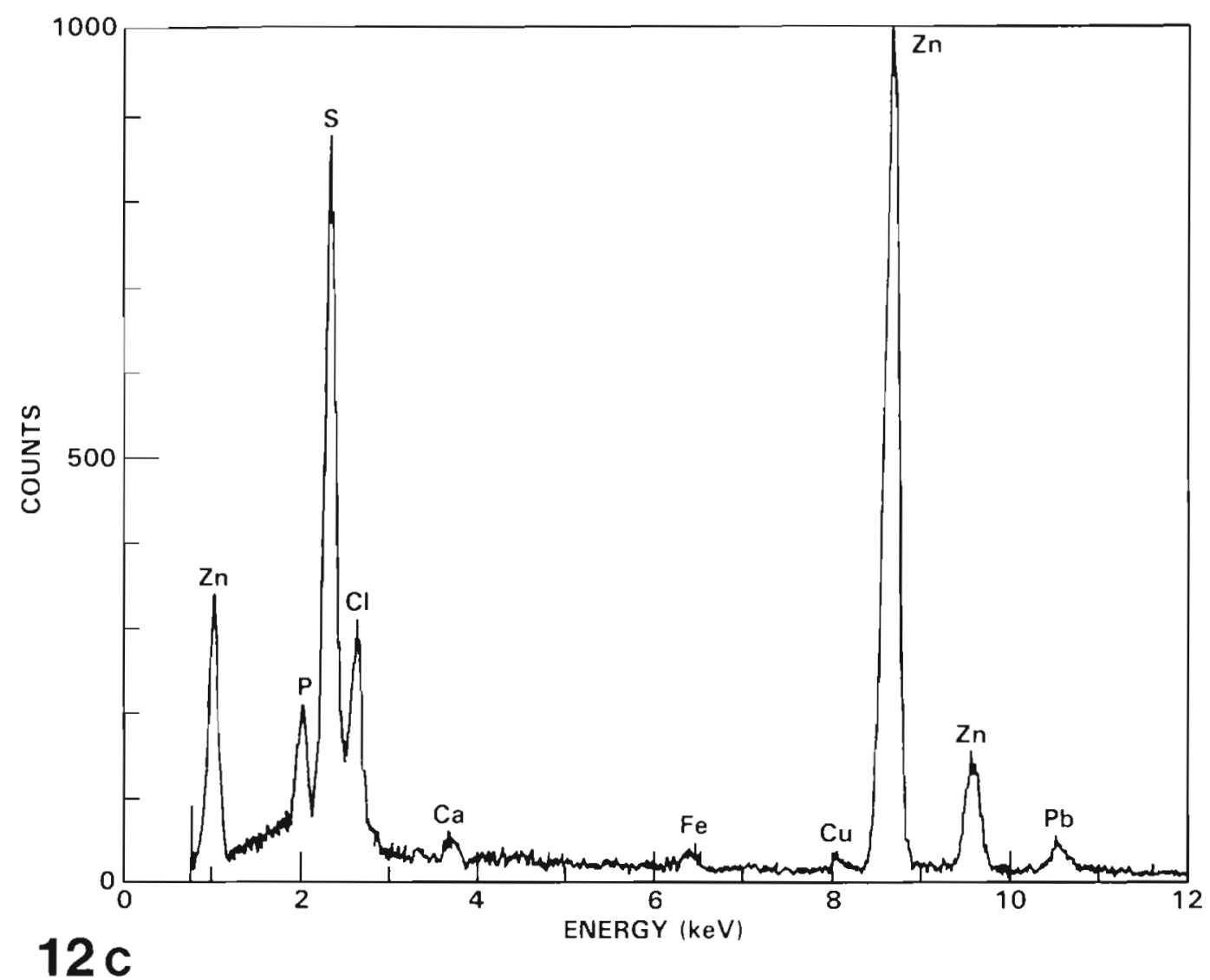

Fig. 12. Mytilus edulis. (a) STEM photomicrograph of a massive concretion in the kidney of a control mussel from Tacoma. Bar $=$ $10 \mu \mathrm{m}$. (b) Higher magnification of the concretion in (a). The concentric nature of the layers is typical of molluscan concretions. $\mathrm{Bar}=1 \mu \mathrm{m}$. (c) Typical $\mathrm{x}$-ray microanalysis spectrum of an electron-dense area of the concretion. Sulfur is from $\mathrm{Na}_{2} \mathrm{~S}$ added to the fixative

Table 4. Mytilus edulis. Condition index $=$ (dry weight soft tissue/shell cavity volume) $\times(100)(\overline{\mathrm{X}} \pm 1 \mathrm{~S} . \mathrm{E} ., \mathrm{n}=10) . \mathrm{ST}=$ transplants from Sequim to Tacoma. TS = transplant from Tacoma to Sequim. SS and TT = mussels which remained at Sequim and Tacoma, respectively

\begin{tabular}{|c|c|c|c|c|c|c|}
\hline \multirow[t]{2}{*}{ Station } & \multicolumn{6}{|c|}{ Sampling interval } \\
\hline & $0 \mathrm{~d}$ & $2 \mathrm{wk}$ & $4 \mathrm{wk}$ & $8 w k$ & $16 \mathrm{wk}$ & $24 w k$ \\
\hline SS & $11.3 \pm 0.8$ & $9.4 \pm 0.8$ & $10.6 \pm 0.6$ & $8.6 \pm 0.9$ & $13.3 \pm 1.3$ & $10.9 \pm 1.2$ \\
\hline ST & & $9.5 \pm 0.9$ & $9.8 \pm 0.9$ & $12.4 \pm 1.2$ & $9.3 \pm 0.6$ & $7.5 \pm 0.8$ \\
\hline $\mathrm{TT}$ & $12.4 \pm 1.1$ & $8.5 \pm 0.8$ & $9.4 \pm 0.8$ & $8.6 \pm 0.8$ & $7.3 \pm 0.5$ & $6.8 \pm 0.3$ \\
\hline TS & & $8.0 \pm 0.7$ & $10.3 \pm 0.6$ & $8.2 \pm 0.6$ & $12.3 \pm 1.2$ & $9.6 \pm 1.1$ \\
\hline
\end{tabular}

content of mussels, although the two were not synchronous. Toward the end of the study, seawater copper concentrations reached levels considered to be acutely toxic to mussels $\left(\sim 100 \mu \mathrm{g} \mathrm{l}^{-1}\right.$; Davenport and Manley, 1978). Tissue copper concentrations rose to very high concentrations; mortalities, however, were unexpectedly low in light of results of copper toxicity experiments conducted in the laboratory (Davenport and Manley, 1978).

Mussels at the Tacoma site (both transplanted and indigenous) did not achieve a steady-state in their trace metal content due to the fluctuating metal con- centrations in the seawater. Thus, the uptake and depuration model (Fig. 1) around which this study was originally designed was not appropriate for the 2 groups of mussels at Tacoma. Accumulation of metals by the mussels was variable and influenced by changes in the net flux of metals (influx minus efflux) in the face of fluctuating external metal concentrations. For the most part, this net flux can be assumed to be positive since bioaccumulation occurred even during periods of concentration declines in the seawater. Such asynchronous changes between mussels and seawater appeared to be heightened when the frequency 
of change in the external environment was of short duration as during the initial stages of this study. The rate and/or direction of change of the biological response was out of phase with that of the seawater under such circumstances. Additionally, the organs for metal concentration were specific for each metal and, at times, better indicators of bioaccumulation than the whole mussel. Under conditions of metal exposure; copper and mercury were concentrated in gills and digestive gland, zinc in the kidney, and silver in the gills. In the case of silver, dramatic changes in the gills were not apparent in the whole mussel.

The results of the reciprocal transplant from Tacoma to Sequim Bay which was intended to simulate an extreme case of recovery from metal exposure generally followed the hypothetical model of Fig. 1. With the exception of zinc, the metal concentrations in the whole animal approached background levels (therefore, those of SS Fig. 2 to 6 ) during the experiment. However, the pattern of metal loss differed with each metal and was strongly influenced by the behavior of organs involved in concentration. Depuration of some metals such as copper in gill, digestive gland, and whole mussel and silver in gills could be described by exponential release models. However, application of such models to other metals was difficult due to delayed release and interorgan redistribution of metals. Zinc and mercury in the whole mussel, for example, exhibited an $8 \mathrm{wk}$ lag before concentrations began to decrease. The zinc decrease appeared to be governed mostly by the activity of the kidney. Mercury was affected by an initial translocation to the digestive glands. Of the metals examined, copper and silver declined at the fastest rates, approaching background levels after about four weeks. Mercury levels required $24 \mathrm{wk}$; whereas zinc was still elevated after $24 \mathrm{wk}$, the duration of this field study.

The relatively rapid metal accumulation by Mytilus edulis at the Tacoma site indicated the presence of chemical forms which were 'available' to the mussels. Phillips $(1976 ; 1977)$ has argued that metal accumulation by mussels should be interpreted as an indicator for the presence of bioavailable forms of metals in seawater rather than as an indicator of their actual concentrations. This argument is supported when comparisons with regard to copper accumulation are made between our results, in which tissue copper was shown to change with changes in total seawater copper, and those of Popham and D'Auria (1982), in which no correlation occurred between copper in mussels and that in seawater over a wide range of total seawater copper concentrations. The differences in these results can undoubtedly be attributed to differences in the chemical speciation of copper in the two studies as Popham and D'Auria (1982) reported that copper in their study was predominantly particulate-bound while that in ours was obviously in a biologically available form. Our measurement of the copper complexing capacity of the Tacoma seawater was $20 \mu \mathrm{g}$ copper $l^{-1}$ using the polarographic technique of anodic stripping voltammetry (unpubl. own data; see Young et al, 1979 for description of technique). Since the complexing capacity can represent the upper limit for biologically unavailable copper (Crecelius et al., 1982), considerable quantities of available copper would be expected at the Tacoma site at times when the complexing capacity was exceeded. These observations emphasize the utility of using biological indicators for the presence of contaminant compounds when the main objective is to monitor for potential environmental or health implications when levels of the biologically available chemical forms are not easily measurable.

The occurrence of the metals copper, zinc, cadmium, and mercury on low molecular weight, metal-binding proteins and the concept of spillover (Brown and Parsons, 1978) have been the object of considerable interest with respect to assessment of exposure to these metals. Past studies (e.g. Bouquegneau, 1979; Roesijadi et al., 1982; Young and Roesijadi, 1983) have supported the role of these proteins in detoxification of metals by marine species. Toxicity, on the other hand, has been attributed to the occurrence of spillover after the metal-binding capacity of these proteins has been exceeded by the exposure (Brown and Parsons, 1978). Evidence for spillover in mussel gills from the Tacoma site was not observed in this study although gills had accumulated high concentrations of copper and mussels were in stress as shown by measurement of condition index. These results were not in accord with previous laboratory studies with mercury-exposed Mytilus edulis (Roesijadi, 1982). Instead, copper on metalbinding proteins, high molecular weight proteins, and the pelleted fraction was directly correlated with the whole gill copper. It is possible that a much greater amount of copper is required to elicit indication of either a protective effect of the metal-binding proteins or spillover in the gills although copper concentrations in both field exposure conditions and in tissues reached extremely high levels.

The presence of zinc and other elements in vesicles (probably lysosomes), granules, and concretions in mussel kidneys reported here emphasized the role of the kidneys in zinc accumulation and closely paralleled the results of other researchers. Concentric concretions and other granules rich in heavy elements have been found in the kidneys of several molluscs (Doyle et al., 1978; Carmichael et al., 1979, 1980; George and Pirie, 1980; George et al., 1980). These bodies have been identified in membrane-bound vesi- 
cles that are associated with and considered to be formed by lysosomes (George et al., 1978; Lowe and Moore, 1979). Their excretion in the urine suggests that they can be a means for elimination of toxic metals (George et al., 1978, 1980; George and Pirie, 1980). The decline of zinc which was observed between 8 and 16 wk following transfer from Tacoma to Sequim may have occurred through such a process. Similar metallic bodies were not detected in the gill or digestive glands which, in this study, were shown to concentrate metals other than zinc.

In summary, the usefulness of mussels as indicators for metal contamination of coastal environments and of mussel transplant protocols is supported by this study. In the case of metals taken up and released relatively rapidly, infrequent sampling may result in erroneous interpretations regarding the history of metal exposure. Experimental studies on the responses of mussels to fluctuating metal concentrations are few (e.g. Davenport, 1977); they would be useful for interpretation of data such as those reported here

Acknowledgements. This study was supported by grant NA81RAD00019 from the Office of Marine Pollution Assessment, National Oceanic and Atmospheric Administration. Instrumental and analytical capabilities utilized were developed through the auspices of the US Department of Energy. Dr. L. E. Thomas, Hanford Engineering Development Laboratory, Westinghouse, provided guidance and assistance in the $\mathrm{x}$-ray microanalysis of samples. N. S. Bloom conducted the metal analyses of the seawater. O. A. Cotter and J.R. Bridge are acknowledged for invaluable technical contributions. Z. A. Mason and 2 anonymous reviewers are acknowledged for suggesting improvements to earlier versions of the manuscript.

\section{LITERATURE CITED}

Bayne, B. L., Brown, D. A., Harrison, F., Yevich, P. D. (1980). Mussel Health. In: The International Mussel Watch. National Academy of Sciences, Washington D. C.

Bloom, N. S., Crecelius, E. A. (in press). Determination of subnanogram per liter concentrations of silver in seawater by cobalt APDC coprecipitation and Freeman graphite furnace atomic absorption spectrometry. Analytica chim. Acta

Bothner, M. H., Robertson, D. E. (1975). Mercury contamination of seawater samples stored in polyethylene containers. Analyt. Chem. 47:592-595

Bouquegneau, J. M. (1979). Evidence for the protective effect of metallothionein against inorganic mercury injuries to fish. Bull. environ. Contam. Toxicol. 23: 218-219

Boyle, E. A., Edmond, J. M. (1974). Determination of trace metals in aqueous solution by APDC chelate co-precipitation. In: Gibb, T. R. P., Sr. (ed.) Analytical methods in oceanography. Advances in Chemistry, Series 147. Am. Chem. Soc., Washington, D. C.

Breteler, R. J., Teal, J. M., Valiela, I. (1981). Retention and fate of experimentally added mercury in a Massachusetts salt marsh treated with sewage sludge. Mar. environ. Res. 5: 211-255
Brown, D. A., Parsons, T. R. (1978). Relationship between cytoplasmic distribution of mercury and toxic effects to zooplankton and chum salmon (Oncorhynchus keta) exposed to mercury in a controlled ecosystem. J. Fish. Res. Bd Can. 35: 880-884

Carmichael, N. G., Squib, K. S., Fowler, B. A. (1979). Metals in the molluscan kidney: a comparison of two closely related bivalve species (Argopecten), using $\mathrm{x}$-ray microanalysis and atomic absorption spectrophotometry. J. Fish. Res. Bd Can. 36: 1149-1155

Carmichael, N. G., Squibb, K. S., Engel, D. W., Fowler, B. A. (1980). Metals in the molluscan kidney: uptake and subcellular distribution of ${ }^{109} \mathrm{Cd},{ }^{54} \mathrm{Mn}$, and ${ }^{65} \mathrm{Zn}$ by the clam, Mercenaria mercenaria. Comp. Biochem. Physiol. 65A: 203-206

Coombs, T. L., George, S. G. (1978). Mechanisms of immobilization and detoxication of metals in marine organisms. In: McLusky, D. S., Berry, A. J. (ed.) Proceedings of the 12th European Symposium on Marine Biology. Pergamon Press, Oxford and New York, p. 179-187

Crecelius, E. A., Hardy, J. T., Gibson, C. I., Schmidt, R. L., Apts, C. W., Gurtisen, J. M., Joyce, S. P. (1982). Copper bioavailability to marine bivalves and shrimp: relationship to cupric ion activity. Mar. environ. Res. 6: 13-26

Davenport, T. J. (1977). A study of the effects of copper applied continuously and discontinuously to specimens of Mytilus edulis (L.) exposed to steady and fluctuating salinity levels. J. mar. biol. Ass. U. K. 57: 63-74

Davenport, T J., Manley, A. (1978). Detection of heightened seawater concentrations by the mussel Mytilus edulis. J. mar. biol. Ass. U. K. 58: 843-850

Davies, I. M., Pirie, J. M. (1978). The mussel Mytilus edulis as a bioassay organism for mercury in seawater. Mar. Pollut. Bull. 9: 128-132

Doyle, L. J., Blake, N. J., Wook, C. C. Yevich, P. (1978). Recent biogenic phosphorite: concretions in molluscan kidneys. Science, N. Y. 199: 1431-1433

Eganhouse, R. P., Young, D. R. (1978). In situ uptake of mercury by the intertidal mussel, Mytilus californius. Mar. Pollut. Bull. 9: 214-217

George, S. G. (1982). Subcellular accumulation and detoxification of metals in aquatic animals. In: Vernberg, W. B., Calabrese, A., Thurberg, F. P., Vernberg, F. J. (ed.) Physiological mechanisms of marine pollutant toxicity. Academic Press, New York, p. 3-52

George, S. G., Pirie, B. J. S. (1980). Metabolism of zinc in the mussel, Mytilus edulis (L.): a combined ultrastructural and biochemical study. J. mar biol. Ass. U. K. 60:575-590

George, S. G., Pirie, B. J. S., Cheyne, A. R., Coombs, T. L., Grant, P. T. (1978). Detoxication of metals by marine bivalves: an ultrastructural study of the compartmentation of copper and zinc in the oyster Ostrea edulis. Mar. Biol. 45: $147-156$

George, S. G., Pirie, B. J. S., Coombs, T. L. (1980). Isolation and elemental analysis of metal-rich granules from the kidney of the scallop, Pecten maximus (L.). J. exp. mar. Biol. Ecol. 42: 143-156

Lawrence, D. R., Scott, G. I. (1982). The determination and use of condition index in oysters. Estuaries 5: 23-27

Lowe, D. M., Moore, M. N. (1979). The cytochemical distributions of zinc ( $\mathrm{Zn} \mathrm{II)} \mathrm{and} \mathrm{iron} \mathrm{(Fe} \mathrm{III)} \mathrm{in} \mathrm{the} \mathrm{common} \mathrm{mussel,}$ Mytilus edulis, and their relationship with lysosomes. J. mar. biol. Ass. U. K. 59: 851-858

Phillips, D. J. H. (1976). The common mussel Mytilus edulis as an indicator of pollution by zinc, cadmium, lead, and copper. I. The effects of environmental variables on uptake of metals. Mar. Biol. 38: 59-64 
Phillips, D. J. H. (1977). The cornmon mussel Mytilus edulis as an indicator of trace metals in Scandinavian waters. I. Zinc and cadmium. Mar. Biol. 43: 283-292

Phillips, J. H. (1980), Quantitative aquatic biological indicators. Applied Science Publishers Ltd., London

Popham, J. D., D'Auria, J. M. (1982). The effects of season and seawater concentrations on trace metal concentrations in organs of Mytilus edulis. Archs environ. Contam. Toxicol. 11: $273-282$

Roesijadi, G. (1980). Influence of copper in the clam Protothaca staminea. Effects on gills and occurrence of copperbinding proteins. Biol. Bull. mar. biol. Lab., Woods Hole 158: $127-138$

Roesijadi, G. (1981). The significance of low molecular weight, metallothionein-like proteins in marine invertebrates: current status. Mar. environ. Res. 4: 167-179

Roesijadi, G. (1982). Uptake and incorporation of mercury into mercury-binding proteins of gills of Mytilus edulis as a function of time. Mar. Biol. 66: 151-152

Roesijadi, G., Drum, A. S. (1982). Influence of mercaptoethanol on the isolation of mercury-binding proteins from gills of Mytilus edulis. Comp. Biochem. Physiol. 71B: $455-459$
Roesijadi, G., Drum, A. S., Thomas, J. M, Fellingham, G. W. (1982). Enhanced mercury tolerance in marine mussels and relationship to low molecular weight, mercury-binding proteins. Mar. Pollut. Bull. 13: 250-253

Roesijadi, G., Hall, R. E. (1981). Characterization of mercurybinding proteins from the gills of marine mussels exposed to mercury. Comp. Biochem. Physiol. C70: 59-64

Ryden, L., Deutsch, H. F. (1978). Preparation and properties of the major copper-binding component in human fetal liver J. biol. Chem. 253: 519-524

Widdows, J., Phelps, D. K., Galloway, W. (1981). Measurement of physiological condition of mussels transplanted along a pollution gradient in Narragansett Bay. Mar. environ. Res. 4: 181-194

Young, J. S., Gurtisen, J. M., Apts, C. W., Crecelius, E. A (1979). The relationship between the copper complexing capacity of seawater and copper toxicity in shrimp zoeae. Mar. environ. Res. 2: 265-272

Young, J. S., Roesijadi, G. (1983). Reparatory adaptation to copper-induced injury and occurrence of a copper-binding protein in the polychaete, Eudystylia vancouveri. Mar. Poliut. Buli. 14: 30-32 